\title{
EXPANDING WORLDS: INTO THE ETHNOGRAPHY OF NARRATING
}

\section{UlfPalmenfelt}

\begin{abstract}
I understand ethnography to mean a description of empirical material that is so meticulous that it constitutes part of the scientific analysis. An ethnography of narrating thus would include thorough descriptions of both the act of narrating itself with all its cultural, social, communicative, and emotional aspects, as well as of the narratives, their form, contents, meaning, function, and aesthetics. Katharine Young's idea of describing a narrative situation as consisting of a number (three, four, or many) of worlds or realms (Young 1987) has proven to be extremely useful and productive. Its analytical strength lies in its ability to provide links between text-centred and performance-centred analyses, especially concerning the roles taken by participants during different phases of the narrative event. When applying Young's model to a short excerpt of a taperecorded life history, its potency of reproduction becomes obvious. First, the speaker appears to set up not one, but a number of parallel taleworlds, occupying different positions in time and/or space. Complicated liaisons are established between temporal and spatial elements of these taleworlds. Second, inside Young's 'Realm of the Ordinary' (or, possibly, parallel to Young's 'realm of thought', 'realm of interaction' or 'social world') there seems to be need for a 'Realm of Experience', where all the not-yet-verbalized actions take place. Furthermore, some taleworlds seem to belong to realms of dreams and imagination, while others are situated in the future; still others (letters, diaries) typically are not performed inside live narrating sessions, but appear in frozen form. At different macrolevels we find the taleworlds of the grand narratives.
\end{abstract}

Key words: narratology, life history narrative, narrative analysis, taleworlds, storyrealms

During the last decades, scholars from several disciplines have taken interest in narrative studies and, even outside the academic world, the word 'narrative' has achieved a broad metaphorical use, with connotations in directions like the inner meaning of..., the consistent essence of... or the symbolic connotations of.... In this paper I wish to develop some of my ideas on how we as folklorists can position ourselves and our field of study in relation to those of our academic colleagues in other fields, doing serious and useful research into the nature of narratives. 
The term narratology itself was coined by literature and culture theoretician Tzvetan Todorov in the late 1960s (Prince 2003: 1; Johansson 2005: 156) to define a field of science that studied the distinctive characteristics of epic texts. To a large extent, the practitioners in this field have been literature scholars, or, at least, the empirical material they have often used was printed literature (Kindt \& Müller 2003). Linguistic conversational analysis typically focuses on interlocutors' technical use of language, but seldom with profound observations of cultural and social aspects that are of interest in folkloristics (Eggins \& Slade 1997; Moerman 1987; Norrby 1996). Oral history discusses the value of oral sources and their relationship to memory, as well as their immanent qualities as narratives (Chamberlain \& Thompson 2004; Thompson 2000). Within social psychology, John Shotter, among others, has studied how individuals construct their worldview through the use of narrative (Shotter 1996). Discourse analysis concentrates on collective corpora of narratives (Winther Jørgensen \& Phillips 2000; Johansson 2005). From all these fields of investigation that border upon - and sometimes overlap with - folkloristics we can learn a lot, both theoretically and methodologically.

To folklorists the study of narratives, of course, is far from new. Since the days of the Grimm Brothers it has been at the core of our academic field (Klein 2006). If I were to summarize the contributions to narrative analysis made by folklorists, I would particularly emphasize three elements.

- First, the central position of fieldwork, whereby we as scholars produce our own empirical material while at the same time acquiring an invaluable first-hand knowledge not only of the material itself, but also of its users and its functions in situations that come close to what we might call authentic.

- Second, the sophisticated methods for painstaking text analyses based on the solid foundation of genre analysis and further developed by several colleagues with inspiration from linguistics and performance theory. The belief that forms in itself is not only a possible but also a worthwhile object of study makes up one of the borderlines separating folkloristics from ethnology.

- Third, and perhaps above all, I would mention our emphasis on the cultural aspects of social interactions, including folklorists' theoretical problematizations of concepts like 'culture', 'tradition', and 'folk'.

An ethnography of narrating, thus, would include thorough descriptions of both the act of narrating itself with all its cultural, social, communicative, and emotional aspects and of the narratives and their form, contents, meanings, functions, and aesthetics. 
In this paper, I will make an attempt to perform an ethnographic analysis of (a part of) a life history narrative. I will use some of the analytical tools invented by other scholars that I find most useful and I will give some suggestions as to how I consider that they might be developed even further.

The narrator in this case is a retired mailman, whom I shall call Edvin, and the material I shall be discussing consists of the first 19 minutes of a life history interview with Edvin. The entire recording is six hours long and in this opening part Edvin recounts memories from his childhood and youth up till the time when he began the job he after that kept for the rest of his life.

A useful tool for narrative analyses is the American folklorist Katharine Young's idea of describing a narrative situation as consisting of a number (three, four, or several) of worlds or realms (Young 1987). The realm of conversation, the storyrealm and the taleworld are the most important. The analytical strength of Young's model lies in its ability to provide links between text-centred and performance-centred analyses, especially concerning the roles taken by participants during different stages of the narrative event.

Before continuing, I want to give you an idea of the content and character of Edvin's narrative by making a short summary of this section. The taperecording starts abruptly with Edvin telling, in a calm, controlled voice, audibly amused, a story about his own sudden birth.

Edvin: in June ... in nineteen hundred and twenty-six ... on a hot summer's day ... thunder ... and rain my mother was, eh, raking grass or hay in the Furulund forest

it was called the school pasture in my time or in those days (smacking his lips)

and she started having labor pains, eh, ran inside, and, eh

probably that's why I've had such, eh, been so hot-tempered all my life except for the last few years

and then I've got to admit...I don't recall much before nineteen thirty ... but it started

that was the best part of my life

I was five years old then ... it was in thirty-one and Johnny and I got a toboggan for Christmas... and there was snow

it had been snowing on Christmas Eve ... and we ran out at once

the other ... the rest of the Chris-Christmas gifts we didn't care about... we just, eh, played with it all day long 
but later on we had a big toboggan with a steering wheel that daddy built

he was a bicycle mechanic ... my father he, eh, he worked in Wigström's bike workshop in Adelsgatan ... and then he opened his own workshop in Hästgatan 24 and ... then ... after a few years he could move to Adelsgatan again...

After that, Edvin describes his own school way by enumerating streets, pathways, shortcuts and directions. In winters, he and seven or eight other boys used to ski to a frozen pond, where they skated on the ice and prepared an icehockey rink. Together with the other boys, Edvin founded a soccer team and they ordered equipment by mail order. They used to go by bicycle to the soccer games, Edvin's father repairing and modifying their bicycles.

Here, Edvin leaves the chronological narrative line to enumerate his brothers and sisters and to give some notes of his older family members' history. After that, he describes some places that were important to him during his childhood.

Once, when Edvin and his younger brother worked as newspaper distributors, they became witnesses to a local hotel's burning. In a more reporting tone, Edvin describes some more of his childhood locations, this time including the people connected to them, for instance, the milk shop lady and the local shoemaker. The hotel fire led his thoughts to the year 1936 and he tells about himself listening to the radio broadcasts from the Berlin Olympic Games. Some years later, Edvin's father got a new job and the family moved again. In this new place, Edvin used to go pigeon hunting on top of a corn silo. Accidentally, he shot himself and after that he had a copper bullet inside one of his fingers for forty years.

After finishing school, Edvin's class went on a journey to the Swedish mainland. Upon their return, Edvin had forgotten that he was supposed to start work the very same day. Instead, he went swimming with a friend, and his future employer came and picked him up at the beach. One day, a customer in the shop, where Edvin was working, was trading eggs for groceries, but forgot to pick up his goods. Edvin had to take the wooden box with the merchandise on his bicycle and catch up with the farmer's horse carriage on the main road south. Another day, when Edvin was bringing some groceries to the employer's daughter's home, the horse was scared at gunshots from some training soldiers.

Edvin started to work in a hardware store, bringing back carbide barrels from the airfield in a truck. Once, he slipped and dropped a 25 kilogram barrel on his foot. Finally, the 19 minutes sequence ends with Edvin reflecting about the working technique of stowing mail sacks in a moving railway wagon. 
Using Young's terminology, we would have to regard Edvin's entire telling as situated inside one and the same taleworld. With the exception of some very brief moments of asides to the interviewer and some affirmative sounds from this person that could be regarded as belonging to the storyrealm or the realm of conversation, the entire 19 minutes sequence is dominated by Edvin's telling. He is the narrator, taking responsibility for the performance in relation to the listener, as well as in directing the actors of the narrative, placing them in the geographical and social environments he himself has chosen. The events retold are all taken from Edvin's memories and given narrative form according to the intrinsic genre demands of the life history story, reconfigured by Edvin's memory slips and deliberate modifications and adjusted to the requirements of the interview situation.

When listening carefully to the tape recording, I can clearly hear how during the telling Edvin's voice shifts in several ways. Sometimes it is strong and self-confident; sometimes it is weak and hesitating. It can be fast, happy, giggling and laughing, or slow, sad, almost sobbing, or calm, neutral, and at ease. Sometimes the mood of his voice corresponds with the language he is using; emphasizing the mood of the narrative, but at other moments there seems to be an incongruity between the mood expressed by the narrating voice, the linguistic constructions, and the atmosphere of the narrated events. In order to trace the patterns of these shifts and incongruities, I will make an attempt to regard Edvin's narrative as moving between separate geographical, temporal, and emotional taleworlds, as well as between the taleworlds of different actors and activities.

I will alternate between the terms 'world' and 'realm' for linguistic reasons only, without giving them any different analytical significance.

From a geographical point of view, Edvin's tale can be understood as enacted in six different taleworlds. Most of the events are situated either in Edvin's domestic area or in what we could call a professional area - that is, a certain part of the local community, where both Edvin himself, and his father and brother used to work in several places. Outside these areas, the narrative also moves into four other places - namely, two recreational areas and two areas for professional excursions.

From a chronological point of view, the tale moves between taleworlds situated in different time segments. The episodes are retold almost exclusively in chronological order, but there are some irregular time jumps making it obvious that there is a difference between the geographical and the temporal taleworlds. At one instant during his tale, for example, Edvin returned to the present time, recounting something that had happened on the morning of the interview; at another moment he delivered some facts about his relatives' 
lives before his own birth. On two occasions he talked about thoughts of his own that are not immediately connectable to any time or place.

Furthermore it could be argued that Edvin's tale navigates between separate emotional taleworlds. His dominant emotional taleworld could be characterized as one of peace, self-confidence and relaxation. We could call it a realm of confidence. Here, Edvin talks in a casual, colloquial language, using long, pre-planned sentences at a steady rhythm. He clearly demonstrates that he is in control of the events taking place in this realm of confidence, even when it concerns dramatic or unpleasant experiences.

We could call the other emotional taleworld Edvin's realm of instruction. Here he assumes the role of a tutor towards the twenty years younger interviewer, lecturing about local history, geography and other circumstances of the past. Here, his manner of speech is slow, thoughtful, and hesitating, with long enumerations and meticulous explanations, making recurring intermissions to make sure that he gets all details correct. A third emotional taleworld could be called the realm of tension. Here, Edvin recounts events that still engage him emotionally, like his shooting accident, the death of his brother, the fire in the hotel, but also the founding of the soccer club or trying to recall the intellectual challenge of planning how to load heavy mail sacks in a moving railway carriage close to a red hot oven without starting a fire. Here, his language is forceful and efficient, changing between long, breathless sentences and short, unfinished fragments, using many direct quotations and exclamations.

From the point of view of action or activities we can identify three major clusters of taleworlds, characterized by what sorts of activities take place inside them. These taleworlds could certainly be outlined geographically on a map, but here I am thinking of their aspect as cognitive spaces in Edvin's mental map. Most central is the realm of professional activities, Edvin's own and his father's and brother's. Scattered around that we find several realms of leisure and, in a quite peripheral position, the realm of Edvin's domestic activities. Like many other Swedish men born in the 1920s, Edvin has obviously not spent much of his lifetime cooking and housekeeping.

Among the actors appearing in Edvin's tale there are at least six different age manifestations of Edvin himself: as an unborn child, as a five-year-old, as a young schoolboy, as a teenager, as a young man, and as a man of the same age as the narrating Edvin. Largest are the taleworlds of the schoolboy Edvin and of the young worker Edvin, which of course is not surprising, since this is the beginning of Edvin's life history. Edvin's father occupies a taleworld of his own, as do some of Edvin's older relatives, whom he has never met. In the taleworlds of the different Edvins, other actors appear, such as his brothers and sisters, 
his schoolmates, teachers, local shopkeepers, employers, customers and other professional contacts. His mother appears just once, in the very first episode of his tale.

The chronological taleworlds follow each other like pearls on a string, making a few irregular loops but mostly running in a straightforward manner. The geographical and emotional taleworlds can be imagined as fields on a twodimensional surface, as can the realms of action and actors.

When I arrange these realms and taleworlds on a map of Edvin's home village, it becomes obvious how deeply his tale is rooted in the geography of his neighborhood, where he has spent most of his life. But we also get a visualization of the mental and emotional organization of Edvin's narrative universe. This is dominated by a huge continent of confidence, embracing most of his domestic and professional realms, as well as the recreational areas of his youth. The activities going on here are work and sports. Inside them, different age manifestations of Edvin appear, constantly busy. Within the space of confidence rises the mountain of education, casting its shadows over much of the narrative landscape. Here, the mature, narrating Edvin becomes visible. Along the periphery of the map, there are two small islands of tension, where the young, inexperienced workingman Edvin is put to the test. Inside the professional realm, there is an area of admiration where Edvin's father runs his successful bicycle business, making mechanical inventions for the benefit of the schoolboy Edvin and his friends.

Inside this mental topography, Edvin's tale navigates, sometimes slowly as on foot or bicycle, sometimes with the seven-league strides of a giant. Some realms and taleworlds are visited repeatedly, others only once.

Rightly, it could be argued that it is quite possible to separate the geographical, chronological and emotional aspects of a narrative, as well as the roles of the actors and actions without using the metaphors of realms and taleworlds. To my mind, however, the idea of imagining a narrative as choreographed inside cognitive landscapes makes it easier both to see some of the narrative constructions and to grasp some of the mental images that the narrator materializes in his narrative. ${ }^{1}$

But let me try to zoom into an even closer perspective. Looking at the contents, these 19 minutes of Edvin's tale may be arranged into 18 or maybe 21 episodes, each of which forms a complete, coherent, if short, narrative in the sense that all of them contain both a complicating action and a resolution (Labov 1972). The experiment I want to undertake now is to regard each of these short narratives as constituting a separate taleworld of its own.

Schematically, the very first episode of the tale could be summarized like this: 


\section{Episode I.}

Time: June 1926.

Place: Furulund forest.

Action: Edvin's mother feels her first labor pains when she is raking grass.

Scenery: Hot summer day with thunder.

Episode's mood: Pastoral idyll, suddenly broken by arriving thunderstorm and birth giving.

Narrative mood: Confidence, positive expectations.

Narrator's stance: Ironic distance, possibly imitating his mother's story, explanation.

Narrative technique: Quasi-literary style that emphasizes the narrative quality and the narrator's distance from the narrated event.

Time is when the recounted event took place according to the narrative, which may be different from what is stated in other sources.

Place, likewise, is where the narrative maintains that the action took place. In some cases it is difficult to decide unambiguously both where and when we should understand the narrated event to take place. For instance, in Episode VIII, Edvin is reporting some facts about his family history, which he had read in his grandfather's notes only some hours before the interview. Edvin's reporting takes place in the here and now of the interview situation. His reading of his grandfather's notebook took place in the very same room a couple of hours earlier. The facts recounted occurred from the late 19th century till just before Edvin was born, but where? In Edvin's mind, family members and relationships probably are connected to places, but this is not always explicit in the telling. We have to accept that enumerations, explanations, orientations, and evaluations generally are not given as fixed, concrete places in the narrative. They could be regarded as temporary excursions from the taleworld into either the storyrealm or the realm of conversation. From listening to the taperecording, however, it is my impression that Edvin never leaves his role as the narrator. Referring to William Labov's terminology (1972), we could perhaps imagine the existence of 'realms of orientation' or 'evaluation' inside the taleworlds.

I use the term scenery for the external setup in a theatrical sense, while episode's mood refers to the prevailing mood or atmosphere of the sequence. In this episode, the setting is staged to produce a maximum effect: some women are peacefully raking hay in a sunny summer meadow, when a thunder storm brakes out, and one of the women, who is pregnant, has to leave the others and run away to give birth. The recounting of such a spectacular incident 
certainly demands the use of a dramatic mode of narrating. I use the term narrative technique to describe such technical, linguistic aspects of the narrator's performance, close to how conversational analysts describe the speech act.

I use the term narrative mood to describe the narrator's attitude in his role as a narrator, which, of course, may be totally different from both the prevalent mood of the narrative and from the narrator's stance as a person. Edvin meets the dramatic demands of the situation in Episode I by using the quasiliterary expression in June ... in nineteen hundred and twenty-six ... on a hot summer day and by adopting the intonation of a movie documentary commentator. The narrative and its setting are both correspondingly dramatic in their mood. By slightly over-emphasizing the dramatic quality of the narrative style, the narrator skilfully creates an ironic distance to the story. I use the term narrator's stance to describe the narrator's attitude as a person, which might differ from his attitude in his role as narrator. In this case Edvin is emphasizing his position as a nonaligned narrator in relation to the narrative. This is further accentuated by his insertion of a piece of geographical information in the middle of the dramatic action.

To sum up my last argument, I think that we have to separate between at least four different levels of mood. Each episode of a narrative possesses modal qualities in relation to our interpretations of the setting, the composition of the actors and the activities performed. The mood of the episode can be strengthened - or called in question, parodied, satirized, or spoken ironically of - by the narrator's role-taking in relation to the narrative. Both the narrative mood and the narrator's stance can be expressed through the narrative technique, in a wide sense. In a formalized situation like a life history interview, it is difficult to form an opinion of the mood of the narrative situation, although it certainly has to be taken into consideration in other cases.

Perhaps an example can help to explain this line of thought:

Once four boys, candidates for confirmation, staged a divine service of their own. One of the boys took the role of the priest, reading from the Bible, while the others personified the congregation. The biblical text was serious and solemn; the boy reading it imitated the voice of the confirmation priest, deliberately making the text even more solemn, thus creating an ironical effect. For all I know, the boy's personal stance towards the Bible text might have been ironical, but he could also have been a strong believer, taking the ironical stance only to evoke the appreciating laughs of the other boys. The mood of the situation could be described as merry, including a slight mockery of the confirmation priest and a possible ironic stance towards the biblical text. 
The narrator's role in relation to his tale can be expressed both through his narrative technique, that is his choice of wording and style, and through what I call narrative mood - that is the attitude of the narrator in his role as narrator of the story. This might coincide with the narrator's stance as a person but must not necessarily do so. As a matter of fact, all these factors may correspond to and support each other or diverge to create effects of irony, parody, satire, and other forms of multivocality.

The entire sequence discussed here was only 19 minutes long. Even so, I found that it could be shown to be composed of several short elements, ranging from 15-20 seconds to a few minutes or from one single sentence to a halfpage transcript. Almost every one of these episodes carried the tale to a place and time separate from the preceding episode, like a filmmaker's cut from one scene to another. In each episode, the speaker's narrative style could be heard to render not only the contents of the episode, but also the proper modal position of that episode inside the totality of the tale, as well as revealing the speaker's attitude both to the event narrated and to the narrative about the event. There are no audible transitions between the separate episodes or taleworlds. Like in a film, they follow immediately upon each other. Unlike the church musician, who has to make a short break to change the registration of his organ, in the narrative (as in a film), the modal re-keying is already done when the performance reaches the audience.

Here I have applied some folkloristic analytical methods on a material produced through folkloristic fieldwork. I have suggested that Katharine Young's model of analysis could be expanded to include temporal, spatial, and emotional taleworlds, as well as realms of actors, of action, of evaluation, and orientation. Furthermore, I have argued that the technique of understanding each separate episode of the tale as a taleworld of its own, made it possible to discern and to separate the mood of the narrative from the mood acted out by the narrator's role, and from the modal stance taken by the narrating person, as well as the modal keying of the narrative situation.

Such a close examination of the formal aspects of the empirical material, however, is only part of the ethnographic analysis. As folklorists we are also interested in what the story is about, the contents, and the cultural context of the tale. A complete ethnography of Edvin's tale would have to take into consideration that this is the beginning of the life history of a Swedish civil servant of the 20th century. We are invited to listen to a retired mailman, looking back with content on his own life and on the development that has taken place during his lifetime in his local neighbourhood as well as his home country. Like everybody else his age, he has experienced sorrow and disappointments during his life, but the dominant mood of his narrative is satisfied confidence. 
Outside the taleworlds that I have been able to show here, Edvin also smoothly links his life history into several political, economical and ideological taleworlds belonging to the realm of the grand narratives of the Swedish Social Democracy of the 20 th century.

To repeat my statement at the beginning of this paper, I believe that one contribution to the expanding academic field of narratology that we as folklorists can make is to develop ethnography of narrating, based on folkloristic fieldwork, on a meticulous analysis of the empirical material and on the urge to emphasize the cultural aspects of the material.

\section{COMMENT}

${ }^{1}$ Perhaps Lauri Honko's concept 'the mental text' (Honko 2000: 18ff.) could be employed to further explore this relationship.

\section{REFERENCES}

Chamberlain, Mary \& Thompson, Paul Richard (eds.) 2004. Narrative \& Genre: Contexts and Types of Communication. Memory and Narrative Series. New Brunswick \& London: Transaction Publishers.

Eggins, Suzanne \& Slade, Diana 1997. Analysing Casual Conversation. London \& Washington: Cassell.

Honko, Lauri 2000. Thick Corpus and Organic Variation: An Introduction. Honko, Lauri (ed.). Thick Corpus, Organic Variation and Textuality in Oral Tradition. Studia Fennica: Folkloristica, 7. NNF publications, 7. Helsinki: Finnish Literature Society, pp. 3-28.

Johansson, Anna 2005. Narrativ teori och metod: Med livsberättelsen i fokus. Lund: Studentlitteratur AB.

Winther Jørgensen, Marianne \& Phillips, Louise 2000. Diskursanalys som teori och metod. Lund: Studentlitteratur AB.

Kindt, Tom \& Müller, Hans-Harald (eds.) 2003. What Is Narratology?: Questions and Answers Regarding the Status of a Theory. Narratologia,1. Berlin \& New York: Walter de Gruyter.

Klein, Barbro 2006. Telling, Doing, Experiencing: Folkloristic Perspectives on Narrative Analysis: Introduction. In: Kaivola-Bregenhøj, Annikki \& Klein, Barbro \& Palmenfelt, Ulf (eds.). Narrating, Doing, Experiencing: Nordic Folkloristic Perspectives. Studia Fennica Folkloristica 16. Helsinki: Finnish Literature Society.

Labov, William 1972. Language in the Inner City: Studies in the Black English Vernacular. Conduct and Communication, 3. Philadelphia: University of Pennsylvania Press.

Moerman, Michael 1987. Talking Culture: Ethnography and Conversation Analysis. Philadelphia: University of Pennsylvania Press. 
Norrby, Catrin 1996. Samtalsanalys: Så gör vi när vi pratar med varandra. Lund: Studentlitteratur AB.

Prince, Gerald 2003. Surveying Narratology. In: Kindt, Tom \& Müller, Hans-Harald [eds.]. What Is Narratology?: Questions and Answers Regarding the Status of a Theory. Narratologia, 1. Berlin \& New York: Walter de Gruyter, pp. 1-16.

Shotter, John 1996. Conversational Realities: Constructing Life through Language (Inquiries in social construction series). London \& Thousand Oaks \& New Delhi: Sage Publications.

Thompson, Paul 2000 (1978). The Voice of the Past: Oral History. 3rd ed. Oxford: Oxford University Press.

Young, Katharine Galloway 1987. Taleworlds and Storyrealms: The Phenomenology of Narrative. Martinus Nijhoff Philosophy Library, Vol. 16. Dordrecht: Martinus Nijhoff Publishers. 